vancing the settlement of the question. In my opinion, there is no improbability inherent in the assumption that hydrogen is but a secondary product, resulting from the interaction of the primary products - water and either carbon or carbon monoxide. The rate at which the interactions take place in flame; are such, and the conditions are such, that the products collected are prob. ably far from being the products of the initial interchanges, as in deed Prof. Smithells himself admits to be the case. It is scarcely likely that the settlement of such a question can ever be achieved by direct observation. Our ultimate views on the nature of the changes occurring in flames must depend on the gradual growth of a true understanding of the nature of chemical interchanges in general, and especially in gases.

I am inclined to take the same view with reference to Davy's explanation of the luminosity of flame. If eventually, as is not improbable, we come to regard the expressions chemical inter. change and electrolysis as interchangeable equivalent terms, much more will have to be said on behalf of Frankland's hypothesis. I had the good fortune to attend the philosophic lectures at the Royal Institution in which Frankland, in 1868, first fully stated his views on this subject, illustrating his arguments by a series of most striking experiments. No course of lectures ever impressed me more, and to the present day I have the most vivid recollection of all that passed. An account af the lectures was published in the Fournal of Gas lighting at the time of their delivery. It has always appeared to me that Frankland's arguments are of a most weighty character, and that owing to their appearance in an obscure publication they have never yet been sufficiently widely considered.

The study of flame affords problems of the highest interest and importance, but of proportionate complexity and difficulty. There is little doubt, however, that we are inclined to take too narrow a view of this as of many otber inquiries-that we have an unreasoning belief in what we are pleased to call facts, forgetting that these same "facts" are but phenomena interpreted by our own limited intelligence. On studying the views that have been taken at various times, it is only too obvious that fashion is not confined only to garments, nor is dogma the exclusive privilege of theologians; and it is time that we realised that very many of our conclusions regarding chemical interchanges are but the crudest dogmas, based on a thoroughly superficial consideration of the phenomena. If we are to deserve the title of scientific workers-workers exact in deed, thought, and word-we must be far more careful in the choice of our language, and guarded in our conclusions.

IENRY E. ARMSTRONG.

\section{"Geology in Nubibus."}

SIR HENRY HowORTH wishes to continue the discussion of glaciation in the pages of NATURE, but I find in his last letter very good reason why this cannot be done. No discussion can lead to definite results unless the parties to it accept as data what they themselves have recently and deliterately admitted. But when I stated that the Rhone glacier did reach the Jura, and deposit on it erratic blocks between Geneva and Soleure, I did so because it was one of the data already admitted by Sir $\mathrm{H}$. Howorth. In his "Glacial Nightmare," pp. 169-173, he gives a full summary of Charpentier's first memoir on the erratic blocks of Switzerland, describing the glacial phenomena exhibited along the whole course of the old glaciers from the Alps to the Jura, and showing that they " even climbed that range and went over to the other side of it." Sir H. Howorth then says: "I have quoted at considerable length from this excellent memoir, because I look upon it as having definitely applied inductive methods to this question with results which are for the most part sound and unanswerable." (Italics mine.) In the same chapter ( $\mathrm{pp}$. 195.202) Charpentier's second memoir is summarised still more fully, and his general conclusion is thus quoted : "It goes without saying that not only all the valleys of the Valais were filled with ice up to a certain height, but that all lower Switzerland, in which we find the erratic débris of the Rhone valley, must have been covered by the same glacier. Consequently all the country between the Alps and the Jura, and between the environs of Geneva and those of Soleure has been the bed of a glacier." Agassiz and other writers are quoted as giving further evidence of the same kind. Nowhere in the whole of this chapter can I find a single objection to the conclusions of the chief writers quoted, and the concluding paragraph, at p. 208, frankly accepts them. It declares that No. I 257 , vor, 49] they are supported by "every form of converging evidence," and that-" "So far there is no question at issue." Yet, when I take these same conclusions of Charpentier as admitted data, Sir II Howorth says: "This form of dogmatic argument is assuredly incomprehensible!" Charpentier's proof that the Khone glacier reached Soleure, was, a year ago, "sound and un answerable," and was an example of "definitely applied inductive methods "; but when $\mathrm{F}$ accept these same results as something to reason upon, I am told that I am making use of "hypotheses outside the laws of nature." I have now justified my opening statement that a discussion carried on in this manner can serve no useful purpose. ATFRED R. WAILACE.

\section{Correlation of Magnetic and Solar Phenomena.}

In Mr. Ellis' letter on this subject (NATURE vol. xlix. pp. 30), he says :-

"To sum up, the points of the matter may be thus stated :(1) The solar outburst in 1859 w'as seen independently by two observers : the fact of its occurrence seems therefore undoubted. (2) The corresponding magnetic movement was small. (3) Many greater magnetic movements have since occurred. (4) No corresponding solar manifestation has been again seen, although the sun has since been so closely watched."

Now, in the year 1882, I was acting as assistant to the Solar Physics Committee, and on November 17 there was a dense fog, so that it was not possible to take the usual solar observations. Mr. Lockyer was present in the morning, and then left for some reason; after he had gone, a tclegram came for him; he returned late in the afternoon, and sent for me, told me the telegram was from Mr. Preece, of the Post Office, asking him whether there was a solar disturbance, as there was such a violent electrical storm raging, that communication had been cut of from the continent, and that it was difficult to maintain communication in England. I at once went to the instruments, and as the fog cleared just before sundown, was able to ascertain that there was a large group of spots near the sun's meridian, attended with most violent uprushes of luminous matter ; indced, if my memory serves me aright, it was the most violent disturbance I saw during the whole of my observations, extending from 1879 to 1886 . On reporting to Mr. Lockyer, he said we should probably see an aurora in the evening; and as soon as it was dark, there was a most brilliant auroral display that exhibited some quite new features (NATURE, vol. xxvii. pp. 82 et seq.) Doubtless, had this spot been kept under observation, luminous outbursts similar to those observed by Carrington and Iodgson would have been seen; indeed, Mr. Whipple's letter (loc.ctt. p. 83) seems to contain such an observation.

I believe, but am not quite sure, as the records of the observations are in Mr. Lockyer's possession, that it was in this spot that he and I first noticed that some of the so-called iron lines in the spot spectrum were in motion, while others were not.

Gunnersbury, November 19.

II. A. LAWRANCE.

\section{New Variable Star in Andromeda.}

A STAR that should be added to the list of variables is $+26^{\circ} 43$, of the Bonn Durchmusterung, in which work its mag. nitude is given as 8.7 . In reply to a letter of mine, in which I expressed a doubt as to this star's existence, Dr. Kuistner, of Bonn, informed me that although he had on the 7 th of this month looked in vain for the star with the 6 -inch refractor of Bonn Observatory, yet it seemed pretty certain that a star had iwice been observed in the specified place in September, 1855 . I have subsequently been informed by Sir Robert Ball, that the star was twice observed at Cambridge (England) in 1878 . The dates and places of the various observations, as well as the estimated magnitudes, are :-

Sept. 7, 1855 , Bonn, $9^{\circ} 0$ (but perhaps $9^{\circ}$ ).

Sept. 10, 1855, Bonn, 8.3.

Nov, 29, 1878 , Cambridge, 8.7

1)ec. 11,1878 , Cambridge, 8.7 .

The star's mean place for $1894^{\circ} \mathrm{O}$ is

$$
\begin{array}{lll}
\text { R.A. oh. r6m. } & 513 \text { ' } \\
\text { Decl. } & +26^{\circ} \quad 24^{\prime} & 27^{\prime \prime}
\end{array}
$$

THOMAS I). ANDERSON。

2 I East Claremont Street, Edinburgh, November 22. 